queira, Qualea spp. The peroba rosa tree is said to attain a height of $125 \mathrm{ft}$. and a diameter of 4-5 ft. in the San Paulo State in Brazil. In less favourable parts of its range, however, it is often less than half this size. It is highly resistant to decay and is easily worked by hand and machine tools.

The name 'mandioqueira' refers to several closely related species of Qualea in the Amazon region. In Central and Southern Brazil the same name is applied to species of Didymopanax, with timber of entirely different character. In Brazil mandioqueira occurs as a large tree mainly of the uplands and the banks of running streams. It probably averages about $100 \mathrm{ft}$. in height at maturity with a diameter of about $2 \mathrm{ft}$. About thirty species of this genus have been recorded from Brazil and the adjoining countries. The timber is moderately hard to work by hand or machine tools, being somewhat cane-like in its resistance to cutting. It is said to be like the African iroko (Chlorophora excelsa) in many respects.

A factor, not without importance in connexion with the research work undertaken by the Forest Products Research Laboratory on these foreign timbers, is in its application among other uses to their suitability or otherwise for plywood conversion.

\section{PETROLEUM: PAST, PRESENT AND FUTURE}

$\mathrm{T}$ HE petroleum supply situation is causing considerable comment in the United States at the present time and no doubt there is the usual crop of rumours concerning imminent scarcity of this product, so necessary in peace-time, so indispensable at this critical period of warfare. Dr. Per K. Frolich has given (Science, Nov. 26 and Dec. 3, 1943) a candid picture of the present position, supported by data from a number of reliable sources. Unhesitatingly he states that eventually a shortage in natural petroleum will occur; but he is equally emphatic that when that time comes it should be possible to obtain all necessary hydrocarbon products from alternative sources. Moreover, there is nothing to indicate that there will be any break in continuity of supply of gasoline and other petroleum derivatives. Nothing more nor less is envisaged than the gradual introduction of synthetic products into the industry as the supply of natural hydrocarbons declines.

Methane, the major constituent of natural gas, can be converted into gasoline by the Fischer-Tropsch process, used commercially in Germany for some considerable time; the heavier constituents can be processed by cracking or dehydrogenation, followed by polymerization and alkylation. Oil can be recovered from shales by 'retorting' under suitable conditions of temperature and pressure. The Tertiary deposits of the Rocky Mountain Region, the Devonian black shales of Indiana and Kentucky, and the cannel shales of Pennsylvania and West Virginia represent a large potential supply of liquid hydrocarbons. In 1928 these deposits were estimated by Dean E. Winchester as capable of producing 92 billion barrels of oil. In addition, there are the Canadian deposits of tar sands which spread over thousands of square miles.

These potential reserves of liquid hydrocarbons are, however, insignificant when compared with the quantity which could be produced from coal deposits. H. L. Ickes, Petroleum Administrator of the United
States, estimated in August 1943 that available coal reserves can provide all the synthetic fuel needed for a thousand years and still leave enough for present purposes.

So far these alternative sources of liquid hydrocarbons have scarcely been tapped in the United States, whence before the War came 63 per cent of the world's petroleum requirements. Indeed, it is unlikely that they will be exploited to any great extent for some time to come. The next phase of development in the petroleum industry, as envisaged by Dr. Frolich, will be characterized by further technological progress, increased drilling for oil on a world-wide basis and necessary adjustments in supply and demand. All these factors will tend to prolong the availability of natural resources and, when peace comes, fear of their imminent exhaustion will loom correspondingly less large.

\section{BOMBAY ISLAND}

$\mathrm{T}$ HE president of the Section of Geology and Geography at the thirty-first session of the Indian Science Congress at Delhi last January was Dr. A. S. Kalapesi, of St. Xavier's College, Bombay. Appropriately, Dr. Kalapesi chose as the subject of his presidential address a review of the geographical and geological features of Bombay Island. His discourse on its geographical aspects is of much interest to those who know Bombay, especially because in describing the evolution of the present unitary island from the earlier seven separate islands (the Heptanesia of Ptolemy) Dr. Kalapesi mentions also the derivation of many of the well-known place names. The word Bombay itself, for example, is now generally accepted as derived from the name, 'Mumba Devi', of the tutelary goddess of the first known inhabitants of these islands, the Kolis.

Geologically, Bombay Island is a portion of the great spread of Deccan Trap lavas occupying so much of Western India, and is composed essentially of westerly dipping sheets of this basaltic formation with a freshwater intercalation, the whole being masked in places by recent sea and lagoon deposits. That there have been geologically recent changes of level is proved by the presence of a raised sea beach in the centre, and of a submerged forest on the east side of the island. The sedimentary bed mentioned above is of special interest as it contains numerous beautifully preserved fossil skeletons of small frogs. The lava sheets of Bombay are thought to be in part of extrusive origin, like the main mass of the Deccan Trap lava flows, and in part of slightly later intrusive origin.

It is evident from Dr. Kalapesi's address and the writings of some of his predecessors (Carter, Wynne and Fox) that what is now needed is a detailed geological study of Bombay Island, including a eareful petrographical study of the various rock types, fortified by chemical analyses. At present views differ, for example, on whether the lava flow that constitutes Malabar Hill, whereon is situated Government House and many of the residences of the merchant princes of Bombay, is composed of basalt, andesite or trachyte. There should be no room for doubt on such a point as this. The task suggested seems a suitable one for geological residents of Bombay, such as Dr. Kalapesi and his students.

L. L. FERMoR. 